\title{
Justice Values in Kenny's Theoretical Contributions
}

\author{
Sue Baines ${ }^{1 *}$ \\ 1 Capilano University, Canada \\ *sbaines@capilanou.ca
}

Received: 24 August 2018 Accepted: 24 September 2018 Published: 15 October 2018

Editor: Katrina McFerran Reviewer: Brynjulf Stige

This article explores Carolyn Kenny's inclusion of justice values in music therapy theory. The International Dictionary of Music Therapy defines social justice as,

A concept that emphasizes a society founded on principles of equality, one that values and promotes human rights ... [It] involves actively working to eliminate structural injustices based upon one group or individual having unfair power or privilege over another group or individual (Hadley, 2013, p. 121).

The way Carolyn Kenny lived her life, her teaching, and her publications, elevated awareness of justice values. Her mindful and reflective practice, combined with intense social and political activism, foundationally influenced by her Native American heritage, informed her personal philosophy and theoretical disposition. In Kenny's (2014) words, "I often think of my Native American mother and her advice to me while I was growing up. She always said: 'Be a human being first. The rest comes later'”. Kenny's focus on being rather than doing opened her consciousness to fostering inclusive, respectful concepts for developing general theory for music therapy that reflected justice values. "Carolyn Kenny ... devoted much of her career to the development of music therapy theory," (Bruscia, 2012, p. 28) and her "theories were meant to apply to all of music therapy" (p. 30). Her story is the story of her contribution to music, health, and social change. This article will reveal this manifestation in her voice through sharing her writings.

Kenny's personal and professional philosophy of experiencing beauty fully and deeply along with her profound relationship with nature was reflected in every aspect of her work with her clients, her teaching, and her writing, a continual expression of her justice values. This personal focus led her to depart from the typical medical and behavioural music therapy theories and incorporate her personal and cultural values and knowledge into her theoretical contributions. Using data from an interview with Kenny, Lindan (2015) created a poetic biography about Kenny's life:

My father's parents fled their home, with light bags and strong bones. Mygrandmother, our pillar. Through each trial, her love prevailed. My mother's mother fled her life, left her little child behind. My mother, heartbroken, came to reject her Choctaw blood. Yet, she spoke her people's wisdom, and she made her peace with them. She made her peace before she travelled through the veil of life and death.

I let her go, compelled to know more about our people's ways. Many nations took me in, called me sister. Called me daughter. Every human is a soul, on whom we can't impose our will. The Spirit will decide, I learned this from my Haida mother. Interwoven plight 
and beauty, stories that elude the mainstream. Stories that infuse my bones to champion from the margins (Lindan, 2015, p. 27).

Kenny's formal studies on how to bridge contemporary music therapy practice and traditional Indigenous healing practices began in 1979. This path was inspired by the teachings of Musqueam Elder Walker Stogan as well as her music therapy practice at the University of British Columbia Department of Psychiatry (Kenny, 2002a) and resulted in her first book, The Mythic Artery: The Magic of Music Therapy (1982). She wrote in the preface:

For I am in many ways only a product of my culture, a culture which has developed mind to amazing lengths and created an ever-increasing hunger for that mind to be satisfied with intellectual insights and understands - an over-abundant assignment of word symbols. As all nature, mind is a thing of great beauty. We tend to get lost in words. We work to understand and describe the things we love. Music is one of these mysteries, which defies description (p. xii).

She also reflected on the inadequacy of scientism in the profession of music therapy.

We speak only of observable data. We superimpose statistical formulae, hoping that if we develop the scientific side, the artistic, spiritual side will magically emerge. We rarely mention that music goes beyond sign to spirit. We describe and develop the objective, knowing all along that the subjective has as much, if not more, influence on our patients, our clients, and ourselves (p. xiii).

She explained:

Music is a resource pool. It contains many things - images, patterns, mood suggestions, textures, feelings, processes. If selected, created and used with respect and wisdom, the clients will hear what they need to hear in the music, and use the ritual as a supportive context (p. 5).

Unlike the medical and behavioural music therapy theories typically employed at that time, the core of this publication reflected the death-birth cycle present in music, myth, and nature. In a subsequent publication in 2002, Kenny discussed The Mythic Artery: The Magic of Music Therapy (1982), sharing how music therapy experiences reflect the totality of life:

The central thesis of this work is that music communicates patterns and structures of tension and resolution that translate into themes of death and rebirth that can be effectively used in music therapy. This work can be characterized as distinctly ecological (2002a).

Kenny explained that, "Poetry and metaphor are always good choices when attempting to translate traditional, indigenous concepts into academic and professional contexts," (2002a). She wrote of death and rebirth in this poem from The Mythic Artery: The Magic of Music Therapy (1982):

I am the tree.

And in this moment of being tree

I experience both the endless struggle and profound beauty of life in the same breath.

We are engaged in a quest for survival and balance.

I hear the music of our dance even through the silence of dark hours.

Soon the leaves on my brother will turn

And leave ... to replenish the earth again.

I too change.

I sometimes die and am reborn.

As long as we share connecting patterns

we are One.

Not I, Not He.

... But whole and sweet life. 
Carolyn Bereznak Kenny, 1979 (1982, p. 31).

I and other music therapists very concerned with the dearth of sociocultural critique in traditional music therapy theories and models of practice happily received Kenny's illumination of the connection between art and science, life and death, music and health, and myth and truth. The Mythic Artery: The Magic of Music Therapy (1982) outlined and set the groundwork for Kenny's subsequent immeasurable contribution to justice values in music therapy theory, research, and practice.

In 1985, Kenny expanded the work of The Mythic Artery: The Magic of Music Therapy (1982), publishing an article that explored the application of whole systems theory to music therapy. She focused on both the relational aspect of music therapy as well as the holistic experience of music therapy.

Music is the expressive connective tissue guiding us into wholeness. It is not only a metaphor, but a living model which resonates the deep truth and beauty contained in the phenomenon of wholeness (Kenny, 1985).

This way of thinking and processing music therapy was very different from the behavioural and medical focus found in theories in general use in music therapy at that time. It provided a holistic framework for music therapy practitioners to think and feel broadly and deeply about their work, engage in reflective practice, and increase ethical inclusive practice.

Kenny followed this article in 1989 with her second book, The Field of Play: A Guide for the Theory and Practice of Music Therapy. Here, she again critiqued music therapy's reliance on medical theories furthering her earlier work to fashion a general theory for music therapy from her profound relationship with the land and all living things as well as her experiences in music therapy. As part of Lindan's (2015) research, Kenny shared:

The Native principle of noninterference is about recognizing conditions, as we do with the land. This is much like The Field of Play. For me, it's not about interventions. It's about paying attention to the conditions and having a sense of mutuality, as opposed to domination. That is why I have a very hard time with behavioural theories. I do not think that we should impose goals and objectives about changing people's behaviour to make society more comfortable (p. 32).

As Kenny wrote in 1989:

The Field of Play suggests an attention to subtleties, quiet and implicit non-verbal cues, which communicate the natural healing patterns of the human person and imply an order which can guide and inform us into the best movement, which will lead us into wholeness (p. 139).

These concepts of mutuality and non-interference reflect the justice values that permeate Kenny's work.

I really feel that our job as music therapists theoretically is to create a space: a space that nurtures growth, but does not determine what that growth should be. In The Field of Play, I give conditions of the space and certain primary principles, like mutuality. But beyond those, I want people to fill it in with their own particulars (Kenny in Lindan (2015, p. 36).

Kenny's second book, The Field of Play: A Guide for the Theory and Practice of Music Therapy (Kenny, 1989), was again deeply appreciated by music therapists like myself who found the on-going focus on the medical model in music therapy an uncomfortable fit with their personal philosophy, theory, and practice of music therapy. Publications followed such as, Aigen's doctoral thesis (1991), which employed his understanding of an Indigenous paradigm to research the roots of music therapy and critique the reliance of music therapy on psychological theories and my Master's thesis (Baines, 1992) that used a feminist framework to analyse sociocultural and political contexts of music therapy illuminating ethical consequences. 
In 1999, Kenny furthered her concepts of general theory in music therapy. She taught her readers that "theories are abstract" (p. 128) and continued:

In general theory, we would like to see general principles which could help us to understand different methods, different populations, different models. We are seeking coherence and subsequent foundational ideas. Nevertheless, this coherence would need to be flexible, if it is to embrace the complexity and difference necessary to be relevant and useful to a large group of music therapists (p. 128).

The construction of general theory will take an honest engagement, one which is constantly monitored by both the acute listening and finely-tuned articulation of each music therapist. How do different music therapists interpret the grand narratives of their region? How can we include music therapists who are not represented in our conversations? How can we gather and interpret data from patient experience with an eye for general theory? (p. 134).

Kenny outlined this process:

As modern intellectuals, we engage in discursive practice. And in the present intellectual climate, if we are playing by the rules of discourse and if we are in the current "thought stream", we refer to ourselves as located, situated, embodied beings. This is context. This is how we identify who we are, where we are from and the details about our location, our situation, our bodies in time and space (p. 127).

In this article, Kenny again shared her core value that aesthetics are central to general theory of music therapy. "When therapist and client are perceived as forms of beauty, it sets the stage for the evolution of music therapy as art" (p. 129).

An aesthetic approach reminds us that we can make sense out of our lives, even when they seem fragmented or chaotic. This coherence comes through authentic expressions in the music. Something settles. Something reassures. Something works when music brings our lives into an aesthetic form. The music therapist, of course, is both participant and witness in this process (p. 129).

This publication expanded her previous writing, challenging her readers to explore music therapy research and practice contextually while listening deeply to the grand narrative of the field.

2001 saw Kenny realize her vision of an open access journal for music therapy Voices: A World Forum for Music Therapy (ISSN 1504-1611). Her commitment to developing justice values in music therapy can be found in the Focus and Scope statement, which reads:

Voices: A World Forum for Music Therapy (ISSN 1504-1611) invites dialogue and discussion about music, health, and social change. The journal values inclusiveness and socio-cultural awareness and has increasingly nurtured a critical edge that refines the focus on cultural issues and social justice. Since its inception in 2001, the editors have been committed to developing an egalitarian and interdisciplinary forum so that multiple voices can be heard. This publication will encourage participation from every continent and will nurture the development of discussion and debate. Because culture has an important role in music and music therapy, we will encourage contributions that find their source in the cultural influences of each continental region (www.voices.no).

And in the Vision Statement, which declares:

Voices: A World Forum for Music Therapy seeks to nurture the profile of music therapy as a global enterprise that is inclusive and has a broad range of influences in the International arena. The forum is particularly interested in encouraging the growth of music therapy in developing countries and intends to foster an exchange between Western and Eastern as well as Northern and Southern approaches to the art and science of music therapy (www.voices.no).

Voices is committed to open access, peer reviewed, with a goal of inviting dialogue and discussion, offers inclusivity, encourages sociocultural critique, and is interdisciplinary. As Kenny wrote in 2001, the "vision for Voices is to encourage a discourse 
between the more isolated tribal societies and the more industrialized societies." Articles are socially, culturally, and academically relevant to support the use of music for social change, and dialogue and critical reflection are promoted to develop interdisciplinary contexts of understanding. The seventeen-year success of this journal can be recognized in the depth and breadth of the writing that challenges and supports music therapists to increase their critical analysis and personal reflection to enhance inclusivity and justice values in their work of using music for social change.

In the third edition of Voices in 2001, Kenny extended her writing on the need for an ecological approach to understanding and practicing music therapy, again putting forward her justice values.

If we imagine that solutions to our dilemmas will only be found in fields of engagement that focus on military, diplomatic and economic solutions, we are badly mistaken. Solutions are found in everyday life. And perhaps the solutions we can discover and create are available to us through collegial relationships and conversations about our work in music therapy. We consider the individual and collective questions. We think about how we can apply sound principles to our work. Often these principles have secure roots in cultural values, beliefs, norms, behaviors, feelings, customs, taboos, languages and other cultural practices (Kenny, 2001).

2002 saw Kenny patiently sharing her perception of how traditional wisdom can be incorporated into music therapy without participating in cultural appropriation, educating the readership on cultural respect.

This is the underlying rationale for the study of concepts rather than imitating practices when it comes to the traditional healing systems of Indigenous peoples. Concepts allow us to engage in the material world as academics without committing the colonizing act of appropriation (Kenny, 2002a).

Kenny wrote that this work strove to "create a definition of ritual that would reflect the concepts of a traditional, indigenous worldview and also be practical for music therapists" (Kenny 2002a). Kenny reflected that "Field theory seemed, in many ways, consistent with the traditional knowledge given to me by indigenous elders" (Kenny 2002a), offering a way to incorporate Indigenous wisdom respectfully.

Continuing her quest for social justice, Kenny penned the anti-war article, Women Must Wait, in 2002 (Kenny, 2002b). Her poetry spoke profoundly of her foundational beliefs and theoretical truths.

\section{Women Must Wait}

Where is the man who in the middle of the water goes while I meanwhile am crying into the long Winter nights with screams which barely cut through times in space where shifts of Earth surprise babes in the night and innocence of all souls?

Is there the sound of blood on some distant fields of sand where gods are more human than we dare to imagine on desert nights?

I wait

And shake

In long nights of grieving women who scream and thrash at old stories we thought would never return from ancient wounds of Earth our ground of being we thought long would be healed now.

Who are these men, my son?

In your voice I hear the call of the old drum that no longer need be played for killing things.

Go away you into the hills now from the sound of blood spilling in spaces where we could embrace and eat Earth.

I am woman who wants to melt away these killing metals though it 
be in ancient screams and hot tears in caves where bewildered spirits crouch in fear of what man has made upon us the Earth.

It is the longest night beyond the Winter Solstice Feast beyond some babe who spoke of love and died beyond the Full Moon when mothers wait for signs of life from distant lands where young men do some useless old piece of hopefully soon to be forgotten thing called war.

Your eyes reach out for my anger at this

You are not afraid.

Can you say the names of all of those who have died?

My scream is reaching out into the night for existence in time itself and after the first rain a dewdrop comforts me and dolphins swimming in waters by my tent on that first day of some new hope for peace to the sound of tears of mothers of sons.

Take me to salt and sea and the dissolution of old ways, of killing things.

Where is the man who waits for peace on sandy shores of quiet places and lights on my fear in a boat where fog and mist cover the edges of harsh words and the letting go of old ways?

(Kenny 2002b).

Kenny continued to support justice values in music therapy and Voices through her writing. For example, in her 2006 article with the poetic title, A World of Full of Voices, Kenny put forward values of inclusivity and respect with her call for integrating nonwesternized concepts into research practices. She remarked:

When non-Western Music Therapists create their research protocols and standards on models from the West, we can use our imagination to balance out the cultural factor in an attempt to avoid hegemony. Hegemony reminds us that any system is embedded with the values and beliefs of the people who created the system. We can ask the question:

What kind of research and standards would these cultures have invented for Music Therapy if they had not had Western models upon which to base their own models?

... we can only function well as global citizens if we embrace the diversity of life, which includes the diversity of standards of practice and research protocols.

The diversity of voices represented in Voices invites us into a shared conversation about how to improve our human condition in old and new ways, diverse ways, without a preordained hierarchy placing West, East, South, and North (Kenny, 2006).

2014 saw Kenny revisit The Field of Play (Kenny, 1989) with a new focus in her article The Field of Play: Ecology of Being in Music Therapy (Kenny, 2014). She wrote, "The Field of Play is a general theory or perhaps a pre-theory or philosophy for music therapy that does not prescribe particular methods of practice like improvisation or imagery with music or other approaches" (Kenny, 2014) and affirmed that:

The Field of Play is all about conditions in the space, the primary one being, as my mother instructed, being and a focus on being. It is a theory that suggests connection to all living things. Imagine a rain forest or a field of daisies-ecosystems just like us with conditions (Kenny, 2014).

Also,

The Field of Play is not a theory about how to do. Rather it is a theory about how to be and how to notice shifts in particular states of consciousness and fields of existence-shifts that carry us along the currents and tides of the great river. It challenges our perception to notice these shifts while simultaneously following our prescribed systems or techniques of 
practice in music therapy, our layers of abstract theories, our cultural mandates, and our personal and professional ethical codes (Kenny, 2014).

Throughout her career, Kenny explored the music therapy space proposing a general theory that addressed the emergent aesthetic self supported in a safe playful space for human growth and development. She critiqued models with expectations of ideal ways to be and live, which venerated the white male. Instead she proposed a more inclusive ecological paradigm leading the way in post-modern theories in music therapy (Baines, 2013). She critiqued traditional approaches to therapy and, like other justice theories, she encouraged storytelling and sharing as a manner of increasing mutuality. In her words:

One of my mentors was a Musqueam elder: Vince Stogan. I would have so many problems at SFU (Simon Fraser University) with people not understanding what I was trying to do up there. So, I call Vince, and I'm crying, and I say: Oh, what am I gonna do, they won't hear anything. And he says: I'll come and buy you coffee. So, he takes me out for coffee, but you know what he does to set up the mutuality? He holds my hand and says: Oh, baby, I wanna tell you what I was doing yesterday. And I'm thinking: I'm sitting here in tears, I'm suffering, and you're telling me what you did yesterday?! But you know what? That was a wonderful way to set up the mutuality. I think we can apply that kind of teaching from an elder to stabilize the relationships in mutuality. By telling our own story .... . In the oral tradition, I learn all kinds of things when people are telling me their stories. The unfortunate thing in our trainings is that we're told to not say much about ourselves to our clients. Well, that's a pile of bunk in the Native world! Because you're like a non-person until you reveal aspects of yourself. I'm imagining being a client with a music therapist sitting in front of me for the first time. As a client, I'm thinking, who is this person as a person? How safe am I? And only when they hear the music therapist's stories, about their vulnerabilities, will they begin to feel this mutuality with the music therapist. So, I think we need to be more self-revelatory (Lindan, 2015, p. 37).

In her writing and her life, Kenny deeply linked her Indigenous knowledge and wisdom with her understanding of music therapy, sharing justice values through her theoretical focus. Furthering the understanding of her readers, she explored the experience of living between two worlds with her colleague, Dr. Richard Vedan, an Indigenous Lodge Keeper and medical social worker. They noted "you have to constantly negotiate the two worlds ... this is true for ... many Native people who are trying to be in the modern world as professionals yet ... have these other identities as Native healers" (Kenny, 2015). Kenny quoted Vedan who stated:

I feel like I have one foot in each culture. It's like I have my left foot in one canoe and the other foot is in another canoe. And I'm in the rapids and I have to deconstruct the canoes from a Western paradigm to a traditional paradigm and not drown in the process and sing songs along the way (Kenny, 2015).

In 2016, Kenny illuminated theory that supported the broad and foundational significance of music in our lives and our communities, sharing how music is effective to create positive social change. She explored "the relationships between land, culture, music, health and healing, and Indigenous societies ... [sharing that] [m] usic has played a central role in our lives since the dawn of our existence as human beings." That, "[s]ocial cohesion, identity formation, memory, [and] virtual time, represent only a few of the important themes about how music performs itself in life-sustaining service" (Kenny, 2016a).

Kenny revealed deeper clarity on her understanding of the relationship between music and play with her stories in the Oxford Handbook of Music Therapy (Kenny, 2016b).

When I was a young classical piano student, I obeyed the nuns who were my teachers. I practiced my scales over and over again, played single measures and longer phrases repeatedly until they reached perfection, memorized Bach, Beethoven, Schuman, and others. The nuns were strict teachers. So I learned to play well. I learned the value of repetition and discipline. But in quiet moments when no one was at home, I put aside the strict protocols and gave myself over to the intuitive spontaneity of improvisation (p.1, ch. 25). 
And:

Improvising created space for me to claim my uniqueness and my spirit. The piano was a play space in which I could move beyond discipline, protocols, imposed structures, and the expectation of others. It was an unconditional space that invited spontaneity and freedom. On days when I was happy, I played my happiness. On days when I was sad, my playing reflected this. (p. 2, ch. 25).

This early childhood learning influenced her understanding of therapeutic experience in music therapy.

One is more likely to access a sense of play when one feels secure. Music therapists work with so many people who are traumatized that a sense of play is far from their awareness. So many people coming to music therapy services are unable to imagine being playful. Once a patient feels secure in the musical space, then, a new field emerges-the field of play. This is not a stage or a level. It is a space with particular conditions and can happen anytime in the therapeutic encounter. The primary condition is safety (p. 7, ch. 25).

There is a paradox in the notion that as we move toward beauty, we move toward wholeness if we accept the premise that we are already whole. But this liminality in our patients and ourselves reminds us that we strive toward a more and more elegant and complex beauty and wholeness over time (p. 9, ch. 25).

It takes a great deal of faith to adopt and adapt the field of play. The boundaries are different every time. There are no concrete controls. There isn't a list of prescribed procedures. The only goal is to play. (p. 12, ch. 25).

If we accept this river, then we can do or try our work as part of a natural process in an ecology of being. This approach mirrors a very important Native American principle-the principle of non-interference. And I can't help but recall the many times I have seen the term "intervention," a kind of interference, used in music therapy literature. Maybe that's why I had to take this journey to find some new language and new concepts for my own practice (p. 12, ch. 25).

Now that I have the field of play I feel liberated from the command and control of language that might inhibit me from the deep and rich human encounters that are available through music in music therapy (p. 12, ch. 25).

Kenny, our teacher in all aspects of death and rebirth, offered this short discussion in Lindan's research:

As a music therapist, you can't always heal people by keeping them alive or changing a behaviour. In my belief system, even death can be a healing. The Spirit has its own life, and it's going to decide about the healing. So I think of a human being as a soul on a journey, and they are the only one that really knows what that journey is (Lindan, 2015, p. 32).

Carolyn Kenny's contribution to justice values in music therapy theory is exponential. She inspired and continues to inspire music therapists globally toward inclusive aesthetically based ethical practice that supports social change. Kenny's use of poetry punctuated her writing with artistry and truth. As such, this poem will complete this article.

\section{Summer Solstice}

\section{Santa Barbara, California, 1980}

The drums of Shiva,

The bells of Islam -

No Marine bands approach

This celebration of Solstice

Bangles, costumes, colors of the East.

South America, the Native Indian

Music of the peoples of Black, Red and Yellow

March on this day 
Through the songs and daughters of the sixties

In Western sun.

Twenty years later they remind us

Of the heartbeat, the breath

What have we left behind?

There is no death

For this culture

Who bears the heartbeat

Across many miles

Where is the myth in our own music?

Hear the beat

It is the same drum.

The cosmic tree

Stretches across the Earth

As does the wind

Who knows no East or West

We assign names to space

But the Earth has one core

Which is always at the center

Hear the mythic music which binds and heals

For sons and daughters

Of East and West.

Carolyn Bereznak Kenny (Kenny, 1982, p. 141).

\section{References}

Aigen, K. (1991). The roots of music therapy: Towards an indigenous research paradigm. New York: New York University. Doctoral Dissertation.

Baines S. (1992). The Sociocultural and Political Context of Music Therapy: A Question of Ethics. Unpublished Thesis Project: New York University.

Baines, S. (2013). Music therapy as an anti-oppressive practice. The Arts in Psychotherapy, 40, 1-5, https://dx.doi.org/10.1016/j.aip.2012.09.003.

Bruscia, K. (2012). Readings on Music Therapy Theory. Gilsum NH: Barcelona Publishers.

Hadley, S. (2013). Social Justice. In K. Kirkland (Ed.), International Dictionary of Music Therapy (p. 121). New York, NY: Routledge.

Kenny, C. (1982). The Mythic Artery: The Magic of Music Therapy. Atascadero, CA: Ridgeview Publishing Company.

Kenny, C. (1985). Music: A whole systems approach. Music Therapy, 5(1), 3-11.

Kenny, C. (1989). The field of play: A Guide for the theory and practice of music therapy. Atascadero: Ridgeview Publ.

Kenny, C. (1999). Beyond this point there be dragons: Developing concepts for general theory in music therapy. Nordic Journal of Music Therapy, 8(2), 127-136.

Kenny, C. (2001). Times of the Tribes: Can we sing this song. Voices: A World Forum For Music Therapy, 1(3), https://dx.doi.org/10.15845/voices.v1i3.61.

Kenny, C. (2002a). Keeping the World in Balance - Music Therapy in a Ritual Context. Voices: A World Forum For Music Therapy, 2(2), https://dx.doi.org/10.15845/voices.v2i2.84.

Kenny, C. (2002b). Women Must Wait. Voices: A World Forum For Music Therapy, 2(3), https://dx.doi.org/10.15845/voices.v2i3.96.

Kenny, C. (2006). A World of Full of Voices. Voices: A World Forum For Music Therapy, 6(2), https://dx.doi.org/10.15845/voices.v6i2.248.

Kenny, C. (2014). The Field of Play: An Ecology of Being in Music Therapy. Voices: A World Forum For Music Therapy, 14(1), https://dx.doi.org/10.15845/voices.v14i1.737. 
Kenny, C. (2015). Balance Between the Worlds: A Conversation with Dr. Richard Vedan. Voices: A World Forum For Music Therapy, 15(3), https://dx.doi.org/10.15845/ voices.v15i3.826.

Kenny, C. (2016a). Judge a Man's Wealth by the Number of Songs He Knows. Voices: A World Forum For Music Therapy, 16(2), https://dx.doi.org/10.15845/voices.v16i2.879.

Kenny, C. (2016b). The Field of Play: A Focus on Energy and the Ecology of Being and Playing. In J. Edwards, The Oxford Handbook of Music Therapy. Oxford University Press.

Lindan, E. (2015). Toward a Socially Just Profession: Perspectives of Music Therapists in Canada(Unpublished major research paper). Waterloo, ON, Wilfrid Laurier University. 